\title{
A new species of the genus Chiromyza Wiedemann (Diptera, Stratiomyidae) from Rio de Janeiro, Brazil
}

\author{
José Roberto Pujol-Luz ${ }^{1}$ \\ 1 Universidade de Brasília (UNB), Instituto de Ciências Biológicas (ICB), Departamento de Zoologia. Brasília, DF, Brasil. \\ ORCID: http://orcid.org/0000-0002-8621-4856. E-mail: jrpujol@unb.br
}

\begin{abstract}
Seven species of the genus Chiromyza Wiedemann are recorded in Brazil: C. brevicornis (Lindner, 1949), C. enderleini (Lindner, 1949), C. leptiformis (Macquart, 1838), C. ochracea Wiedemann, 1820, C. stylicornis (Enderlein, 1921), C. viridis Bezzi, 1922 and C. vittata Wiedemann, 1820. Herein I describe a new species, Chiromyza raccai sp. nov., based on 88 specimens (41 males, 47 females) from the Atlantic Rain Forest mountains of State of Rio de Janeiro, Brazil, in the city of Miguel Pereira. The new species is distinguished from the related species C. ochracea and C. vittata by the structure of male terminalia. Chiromyza raccai sp. nov. has the distal region of the phallus rounded with two conspicuous apical setae, C. ochracea has the distal surface of the phallus wide and flatness, and C. vittata has the distal surface of the phallus rounded with outer margin rugose.
\end{abstract}

Key-Words. Atlantic Rain Forest mountains; Brown Soldier-fly; Coffee root fly; Chiromyzinae; Neotropics; Taxonomy.

\section{INTRODUCTION}

The Chiromyzinae is a monophyletic group of soldier flies within Stratiomyidae (Woodley, 2001). It is composed by 13 genera and 56 species that occur in the Neotropical and Australasian regions (Woodley, 2001; Lessard et al., 2020). One of these species, Inopus rubriceps (Macquart, 1847), was introduced in the Nearctic region and, there are no records of this subfamily in the Afrotropical region (Woodley, 2001; Hauser et al., 2017, Lessard et al., 2020). The brownish soldier flies are recognized by the following set of characters: (i) reduction of pieces in the mouthparts of adults; (ii) females with robust, elongate and strongly tapered abdomen, presumably modified for oviposition in the soil; (iii) well-developed mandibles in the larvae, presumably to feed of roots, rhizomes and stems, instead of the mandibular-maxillary complex as in other soldier flies larvae, used to filter organic particles, or small organisms, from a moist rotting substrates; (iv) larval body with 12 segments - the species in the other groups have bodies with 11 segments (see Woodley, 2001; Pujol-Luz \& Vieira, 2000; Lessard et al., 2020).

After Wiedemann (1820) description of the genus Chiromyza, Hardy (1920) and Bezzi (1922) presented the first taxonomic revision for Chiromyza. In Hardy's (1920) revision of the tribe Chiromyzini recognized 11 species of Chiromyza, however, nowadays only five of these species are accepted for the genus viz. Chiromyza vittata Wiedemann, 1820, C. ochracea Wiedemann, 1820, C. leptiformis (Macquart, 1838), C. prisca Walker, 1852 (= C. matruelis Enderlein, 1921), C. vicina Bigot, 1879 and, C. grandicornis (Hardy, 1920) (currently Inopus grandicornis). Finally, Bezzi (1922) in a revision of the South American Chiromyza described two other species for the genus: C. nigra Bezzi, 1922 and C. viridis Bezzi, 1922.

More recently, two works expanded the knowledge of Chiromyzinae. Daniels (2016) proposed the genus Metridius and described two species from Australia. The other work presented a generic revision for the Australian Chiromyzinae (Lessard et al., 2020). They also proposed new taxonomic limits for the genus Chiromyza (= Archimyza Enderlein, 1921 and = Stenimas Enderlein, 1921) and transferred five species of these genus from the Australian region to Chiromyza, viz: C. australis (Macquart, 1850), C. ava (Enderlein, 1921), C. matruelis (Enderlein, 1921), C. stemmaticalis (Enderlein, 1921) and C. vicina Bigot, 1879.

Nowadays, the genus Chiromyza groups 19 species: C. australis (Macquart, 1850), C. ava (Enderlein, 1921), C. brevicornis (Lindner, 1949), C. enderleini (Lindner, 1949), C. fulva Nagatomi \& Yukawa, 1969, C. gressitti Nagatomi \& Yukawa, 1969, C. leptiformis (Macquart, 1838), C. matruelis (Enderlein, 1921), C. nigra Bezzi, 1922, C. ochracea Wiedemann, 1820, C. papuae Nagatomi \& Yukawa, 1969, C. sedlaceki Nagatomi \& Yukawa, 
1969, C. stemmanticalis (Enderlein, 1921), C. stylicornis (Enderlein, 1921), C. tenuicornis (Lindner, 1949), C. tristrigata (Enderlein, 1921), C. vicina Bigot, 1879, C. viridis Bezzi, 1922 and C. vittata Wiedemann, 1820. Seven of them were recorded for Brazil: C. brevicornis, C. enderleini, C. leptiformis, C. ochracea, C. stylicornis, C. viridis and C. vittata.

The Brazilian species Chiromyza were seldom investigated. The larvae of Chiromyza sp. were reported as a pest of Coffea arabica Linnaeus, 1753 (D'Antônio, 1991; Lima \& Racca Filho, 1996). Pujol-Luz (1999) breed larvae of this species in the laboratory and after the emergence, identified the imagoes as C. vittata. Later, Pujol-Luz \& Vieira (2000) described the larva of $C$. vittata, and based on the natural history data they gathered, the authors stated that the adults do not cause any damage to the coffee plants. The mass of eggs is deposited in the crevices of the trunks, and after hatching the larvae moves towards the ground, bury themselves and begin feeding on the plant's roots. Herein I describe a new species, Chiromyza raccai sp. nov., based on 88 specimens $(41$ males, $47 \mathrm{fe}-$ males) from Atlantic Rain Forest on the mountains of State of Rio de Janeiro, in the city of Miguel Pereira.

\section{MATERIAL AND METHODS}

Material examined and photography: I examined 86 specimens from the State of Rio de Janeiro, RJ, Brazil: 40 males and 46 females collected in the mountains of State of Rio de Janeiro in the City of Miguel Pereira (22 $27^{\prime} 54^{\prime \prime} S$, $43^{\circ} 27^{\prime} 56^{\prime \prime} \mathrm{W}$ ) and, a couple in tandem from the City of Valença, also in the State of Rio de Janeiro $\left(22^{\circ} 14^{\prime} 46^{\prime \prime} S\right.$, $\left.43^{\circ} 42^{\prime} 11^{\prime \prime} \mathrm{W}\right)$. Microphotographs of the specimens were produced with a Leica DFC295 camera attached to a Leica M205-C stereomicroscope and a Leica DM200 light microscopy. The measurements ( $\mathrm{mm} ; \mu \mathrm{m})$ of the specimens were made using Leica software LAS-V3.8. The holotype and paratypes are housed in the Coleção Entomológica do Departamento de Zoologia da Universidade de Brasília, Brazil (DZUB). The terminology for describing the structures of the external morphology of the flies follows Pujol-Luz \& Oliveira (1999) and Cumming \& Wood (2017). I also examined the photographs of the syntypes (NMW) of C. ochracea, two males, and C. vittata, three females. To compared morphology of male genitalia, specimens previously identified as C. ochracea (MNRJ $=2 ; \mathrm{MZUSP}=1$, UFRRJ $=1$ ) and C. vittata (MNRJ = 2; MZUSP = 1, UFRRJ = 1, $\mathrm{DZUB}=2$ ) was dissected.

Abbreviations used to wing venation: $A_{1}=$ first branch of anal vein; $\mathrm{br}=$ basal radial cell; $\mathrm{C}=$ costal vein; $\mathrm{Cu}=\mathrm{cu}$ bital vein; $\mathrm{CuA}=$ anterior branch of cubital vein; $c u a=$ anterior cubital cell; $\mathrm{CuA}+\mathrm{CuP}=$ anterior branch of cubital vein + posterior branch of cubital vein; $\mathrm{CuP}=$ posterior branch of cubital vein; $d=$ discal cell; $h=$ humeral cross vein; $M=$ medial vein; $M_{1}=$ first medial branch; $M_{2}=$ second medial branch; $\mathrm{M}_{4}=$ fourth medial branch; $\mathrm{m}-\mathrm{Cu}=$ medial-cubital cross vein; $m-m=$ medial cross vein; $R_{1}=$ anterior branch of radius; $\mathrm{R}_{2+3}=$ fused second and third radial branch; $\mathrm{R}_{4+5}=$ third longitudinal vein; $\mathrm{r}-\mathrm{m}=$ radial-medial cross vein; $\mathrm{Sc}=$ subcostal vein .

\begin{abstract}
Abbreviations used to male and female terminalia: apc $s$ = apical setae; cap dct = capsular duct; cerc = cercus; ej apod = ejaculatory apodeme; epand = epandrium; fla sur = flat surface; gen fk = genital fork; goncx = gonocoxite; goncx apod = gonocoxal apodeme; hypd = hypandrium; lat ovid = lateral oviduct; $\mathrm{ph}=$ phallus; $\mathrm{pm}$ sh = parameral sheath; rur sur = rugose surface; spmth cap = spermathecal capsule; $\mathrm{vl}=$ valve.
\end{abstract}

Acronyms for collections: DZUB = Coleção Entomológica do Departamento de Zoologia, Universidade de Brasília, Brazil; MNRJ = Museu Nacional da Universidade Federal do Rio de Janeiro, Brazil; MZUSP = Museu de Zoologia da Universidade de São Paulo, Brazil; NMW = Naturhistorisches Museum Wien, Germany; UFRRJ = Universidade Federal Rural do Rio de Janeiro.

\section{RESULTS}

\section{Chiromyza raccai, new species}

Diagnosis: Body brownish, thorax with four conspicuous dark brown stripes; membrane of wings strongly darkened around longitudinal and transversal veins; legs mostly yellowish-brown, tibiae club-like, with base narrowed and apex enlarged, tibiae patterned in females, with femora with basal $2 / 3$ dark brown and distal $1 / 3$ brownish yellow, tibiae with basal $1 / 3$ brownish yellow and distal $2 / 3$ dark brown; abdomen light brown; hypandrium with posterior margin triangular and apex extending beyond base of gonostylus insertion, phallus tubular with distal extremity rounded with two conspicuous apical setae; female genitalia with genital fork rectangular, fork arms tapering, two lateral membranous oviducts, spermathecae with three long glandular ducts, each one with valve in the distal $1 / 3$, ending in a semi-spherical and strongly sclerotized spermathecal capsule.

Type material: The male Holotype male is housed in the Coleção Entomológica do Departamento de Zoologia da Universidade de Brasília (DZUB), Brasília-DF, Brazil, and labeled:Miguel Pereira-RJ/F. Racca Fo col./30.VII.1998[white label]; Holótipo [red label]; UnB-237877 [white label]. Complementary material: Paratypes (males), labeled: Miguel Pereira-RJ/ F. Racca Fo col./ VI.1996 [white label]; Parátipo [green label]; 9 [UnB-237844-237852]; Miguel Pereira-RJ/ 30.VII.1996, 600m/ F. Racca Fo col. [white label]; Parátipo [green label]; 5 [UnB-237853-237857]; Miguel Pereira-RJ/ VIII.1996, 600m/ F. Racca Fo [white label]; Parátipo [green label]; 1 [UnB-237858]; Miguel Pereira-RJ/ IX.1996, 600m/ F. Racca Fo [white label]; Parátipo [green label]; 1 [UnB-237859]; Miguel Pereira-RJ/ F. Racca Fo col. [white label]/ 30.VII.1998, 600m/; Parátipo [green label]; 16 [UnB-237860-237875]; Miguel Pereira-RJ/ F. Racca Fo col. [white label]/ 04.VIII.1998, 600m/; Parátipo [green 

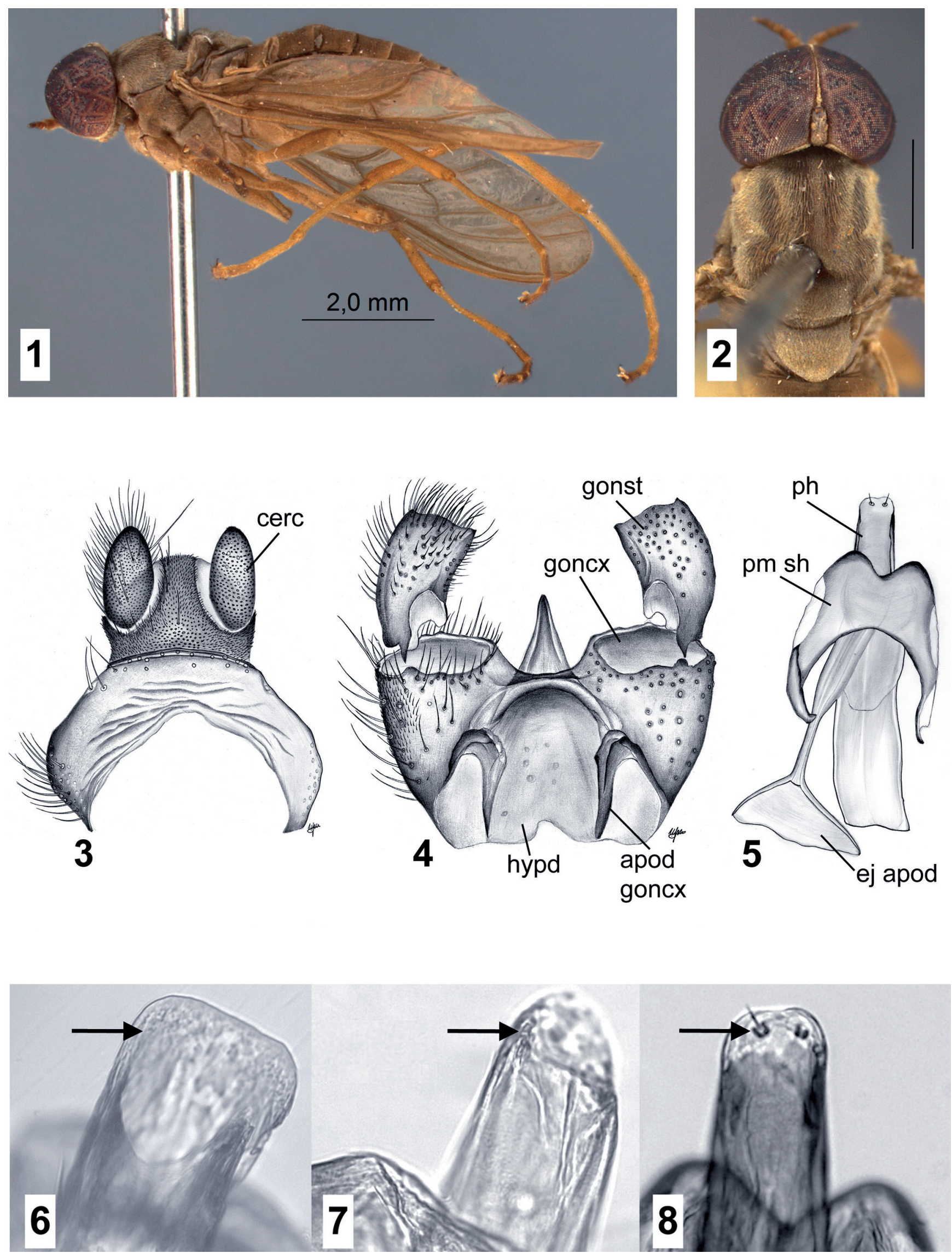

Figures 1-8. Chiromyza raccai sp. nov. (1) habitus in lateral view (Holotype male), (2) head and thorax in dorsal view (Holotype male, scale = $1 \mathrm{~mm}$ ), (3) epandrium and cerci in dorsal view, (4) terminalia in dorsal view, (5) phallus, parameral sheath and ejaculatory apodeme in dorsal view, (6) phallus of $C$. ochracea in dorsal view, black arrow indicating flat surface; (7) phallus of C. vittata, black arrow indicating rugose surface; (8) phallus of C. raccai sp. nov. black arrow indicating apical setae. Abbreviations: Male genitalia: cerc = cercus; ej apod = ejaculatory apodeme; epand = epandrium; goncx = gonocoxite; goncx apod = gonocoxal apodeme; hypd = hypandrium; ph = phallus; pm sh = parameral sheath. 

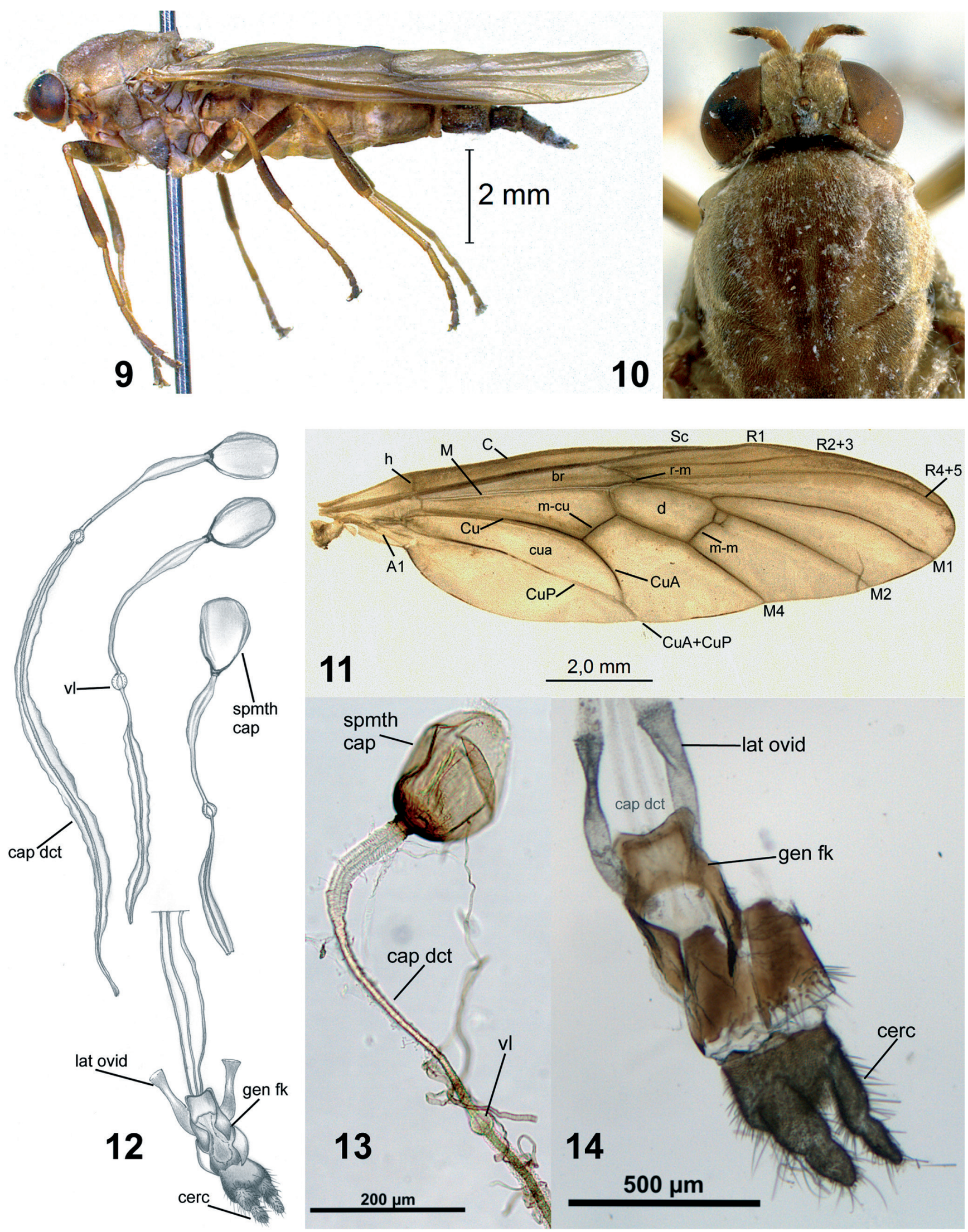

Figures 9-14. Chiromyza raccai sp. nov. (Paratype, female) (9) habitus in lateral view, (10) head and thorax in dorsal view, (11) right wing in dorsal view, (12) terminalia and spermathecae, (13) duct and spermathecal capsule, (14) epandrium, cerci, genital fork, oviducts and capsular ducts of spermathecae. Abbreviations: Female genitalia: cap dct = capsular duct; cerc = cercus; epand = epandrium; gen fk = genital fork; lat ovid = lateral oviduct; spmth cap = spermathecal capsule; $\mathrm{vl}=$ valve. Wing: $A_{1}=$ first branch of anal vein; $b r=$ basal radial cell; $C=$ costal vein; $C u=$ cubital vein; $C u A=$ anterior branch of cubital vein; cua $=$ anterior cubital cell; $\mathrm{CuA}+\mathrm{CuP}=$ anterior branch of cubital vein + posterior branch of cubital vein; $\mathrm{CuP}=$ posterior branch of cubital vein; $d=$ discal cell; $h=$ humeral cross vein; $M=$ medial vein; $M_{1}=$ first medial branch; $M_{2}=$ second medial branch; $M_{4}=$ fourth medial branch; $m$ - $c u=$ medial-cubital cross vein; $m-m=$ medial cross vein; $R_{1}=$ anterior branch of radius; $R_{2+3}=$ fused second and third radial branch; $R_{4+5}=$ third longitudinal vein; $r-m=$ radial-medial cross vein; $S c=$ subcostal vein. 
label]; 1 [UnB-237876]. Paratypes (females), labeled: Miguel Pereira-RJ/ F. Racca Fo col./ VI.1996 [white label]; Parátipo [green label]; 8 [UnB-237878-237885], Miguel Pereira-RJ/ F. Racca Fo col./ VI.1996 [white label]; Parátipo [green label]; 4 [UnB-237886-237889]; Miguel Pereira-RJ/ F. Racca Fo col./ VII.1996 [white label]; Parátipo [green label]; 1 [UnB-2378490]; Miguel Pereira-RJ/ F. Racca Fo col./ VIII.1996 [white label]; Parátipo [green label]; 7 [UnB-237891-237897]; Miguel Pereira-RJ/ F. Racca Fo col./ 09.VI.1998 [white label]; Parátipo [green label]; 3 [UnB-237898-237900; 237908]; Miguel Pereira-RJ/ F. Racca Fo col./ 30.VII.1998 [white label]; Parátipo [green label]; 7 [UnB-237901-237907]. Paratypes dissected (males), Miguel Pereira-RJ/ F. Racca Fo col./VI.1996 [white label]; Parátipo [green label]; 3 [UnB-237909-237911]; Miguel Pereira-RJ/ VIII.1996, 600m/ F. Racca Fo [white label]; Parátipo [green label]; 1 [UnB-237912]; Miguel Pereira-RJ/F. Racca Fo ${ }^{\circ}$ col. [whitelabel]/30.VII.1998,600m/; Parátipo [green label]; [UnB-237913-237914]; Valença-RJ/ Pujol-Luz col./ 13.VIII.1997 [white label], Parátipo [green label]; 1 [UnB-237981 ]. Paratypes dissected (females), Miguel Pereira-RJ/ F. Racca Fo col./ 30.VII.1998 [white label]; Parátipo [green label]; 9 [UnB-237915-237923]; Miguel Pereira-RJ/ F. Racca Fo col./ VI.1996 [white label]; Parátipo [green label]; 2 [UnB-237924-237925]; Miguel Pereira-RJ/ F. Racca Fo col./ VIII.1996 [white label]; Parátipo [green label]; 1 [UnB-237926]; Miguel Pereira-RJ/ IX.1996, 600m/ F. Racca Fo [white label]; Parátipo [green label]; 1 [UnB-237927]; Miguel Pereira-RJ/ F. Racca Fo col. [white label]/ 04.VIII.1998, 600m/; Parátipo [green label]; 1 [UnB-237928]; Miguel Pereira-RJ/ F. Racca Fo col./ 1996, 600m [white label]; Parátipo [green label]; 1 [UnB-237929]; Valença-RJ/ Pujol-Luz col./ 13.VIII.1997 [white label], Parátipo [green label]; 1 [UnB-237985].

Etymology: This name is given in homage to the Professor of Entomology Francisco Racca Filho, Universidade Federal Rural do Rio de Janeiro. Thank you, my dear friend, for your friendship and all specimens collected in the backyard of your house in the Miguel Pereira mountains.

Male: Measurements: Body length: $7.7 \mathrm{~mm}$; wing: $6.99 \mathrm{~mm}$ (Fig. 1). Body brownish, uniformly covered with short pilosity; thorax with four conspicuous dark brown stripes or inconspicuous in newly emerged specimens (Fig. 2). Head: hemispherical; eyes holoptic, glabrous; ocellar triangle prominent, with small ocelli. Mouthparts are vestigial with short 1-segmented brownish-black palps. Antennae light brown, except flagellum, brown to dark brown; scape and pedicel with long dark setae. Pedicel longer and wider than scape; flagellum with three flagellomeres (Fig. 2). Thorax: mostly light brown, densely setose, with four longitudinal stripes (Fig. 2), extend from pronotum to base of the scutellum. Scutellum trapezoidal with posterior margin rounded. Legs mostly yellowish-brown; coxae, trochanters and femora uniformly covered by short setae; tibiae club-like with base narrowed and apex enlarged, more conspicuous in hind legs (Fig. 1); tarsomeres (I-V) longer than tibiae, covered

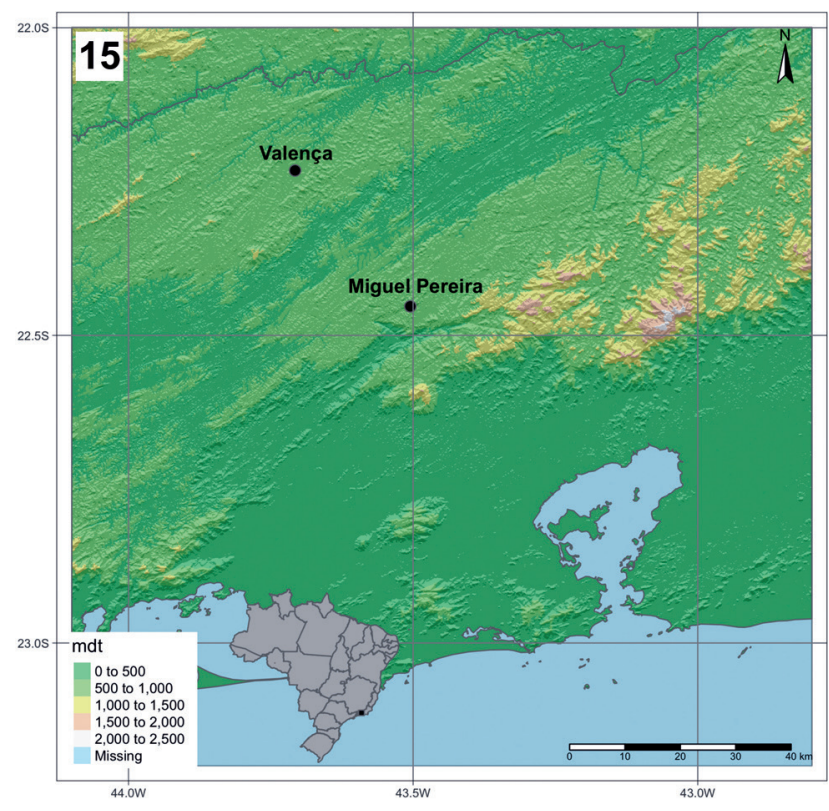

Figure 15. Chiromyza raccai sp. nov. (15) records of geographical distribution in Rio de Janeiro mountains.

with short and dark setae; claws black and well developed. Wings: longer than length of body (Fig. 1), rounded at apex; hyaline membrane with very short microtrichia; vein Sc present; veins $\mathrm{R} 1$ and $\mathrm{R}_{2+3}$ evanescent, transverse vein $r-m$ present, short; $R_{4+5}$ present and reaching wing margin above apex; discal cell (d) well-developed, trapezoidal; veins M1, M2, M4 present and reaching posterior margin of wing; cua present; $\mathrm{CuA}+\mathrm{CuP}$ reaching anal margin of wing (Fig. 11). Abdomen: light brown, with eight segments little sclerotized, slender and elongated; terminalia with genital capsule composed by the epandrium, proctiger and cerci dorsally (Fig. 3) and hypandrium, gonocoxites, gonostylus (Fig. 4) and phallus (aedeagus) (Fig. 5). Epandrium and proctiger with rounded margins, mostly covered by long brown setae. Cerci long and cylindrical, densely covered by fine brown setae (Fig. 3). Hypandrium with posterior margin triangular with margins folded inward, apex extending beyond

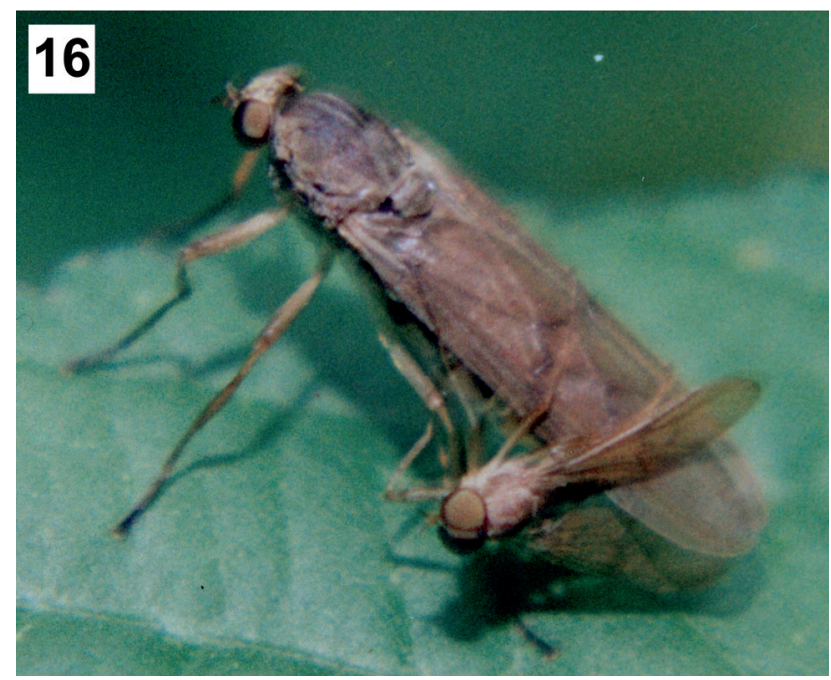

Figure 16. Chiromyza raccai sp. nov. (Paratypes male and female) (16) couple in tandem. 
base of insertion of gonostylus (Fig. 4). Gonocoxites wide and tubular, short; gonocoxites apodems subparallel, not exceeding anterior margin of genital capsule. Gonostylus rectangular, slightly curved inwards and densely covered with long black setae; concave in dorsal surface. Phallus tubular with distal extremity rounded bears two conspicuous apical setae; basal extremity truncated. Parameral sheath and ejaculatory apodeme well developed (Fig. 5).

Female: Measurements: Body length: $15.84 \mathrm{~mm}$; wing: $14.65 \mathrm{~mm}$ (Fig. 9). Differs from male in the following aspects: Body brownish, mostly covered with short setae; body length twice, or more, greater than male. Head: eyes dichoptic (Fig. 10), with short and sparse setae; ocellar triangle strongly prominent, with reddish ocelli. Front almost as wide as long, with a longitudinal depression that reaches base of antennae. Antenna with pedicel wider than all other segments and with short setae; flagellum narrowed, second and third flagellomeres dark brown to black (Fig. 10). Thorax: with four conspicuous large dark brown stripes (Fig. 10). Femora with basal $2 / 3$ dark brown and distal $1 / 3$ brownish yellow, tibiae with the basal $1 / 3$ brownish yellow and distal $2 / 3$ dark brown (Fig. 10). Wings: dark brown veins, membrane of wing around veins and discal cell (d) strongly darkened, venation similar to male (Fig. 11). Abdomen: very long, little sclerotized and inflated, wide at base and tapering at apex to form a long ovipositor; abdominal sternites short, segments 1-4 brownish, segments 5-10 dark brown to black (Fig. 9); terminalia with 2-segmented cerci (Figs. 12-14), yellowish, and covered by long setae (Fig. 14); genital fork rectangular, fork arms tapering (Figs. 12, 14); two lateral oviducts, membranous (Figs. 12, 14); spermathecae with three long glandular ducts, each one bears with a valve in distal $1 / 3$, ending in a spermathecal capsule, semi-spherical and strongly sclerotized (Figs. 12, 13).

Geographical distribution: BRAZIL, Rio de Janeiro, City of Miguel Pereira, City of Valença (Fig. 15).

\section{REMARKS}

I had the opportunity to observe a couple of $C$. raccai sp. nov. in tandem, in the city of Valença (RJ) (Fig. 15). Before perching, the female made a weak flight, guiding the coupled male upside down, through the leaves of a bush. After perching (Fig. 16), she remained with legs stretched out, until the male was positioned laterally (Fig. 16). The rhythmic movements of the couple's abdomen suggested the beginning of copulation (sperm transfer). The couple stayed in the same position for more than 20 minutes. Then, the female began to move and walk on the leaf, dragging the male, who remained attached and immobile, with closed wings. At that time, they were collected. After four hours, in the laboratory, the female oviposited about 250 translucent green eggs, with the surface of the chorion ornamented by small hexagonal cells. No larvae hatched from these eggs.

I compared Chiromyza raccai sp. nov. with photographs of the syntypes (NMW) of C. ochracea, two males (Figs. 17-22), and C. vittata, three females (Figs. 23-31)

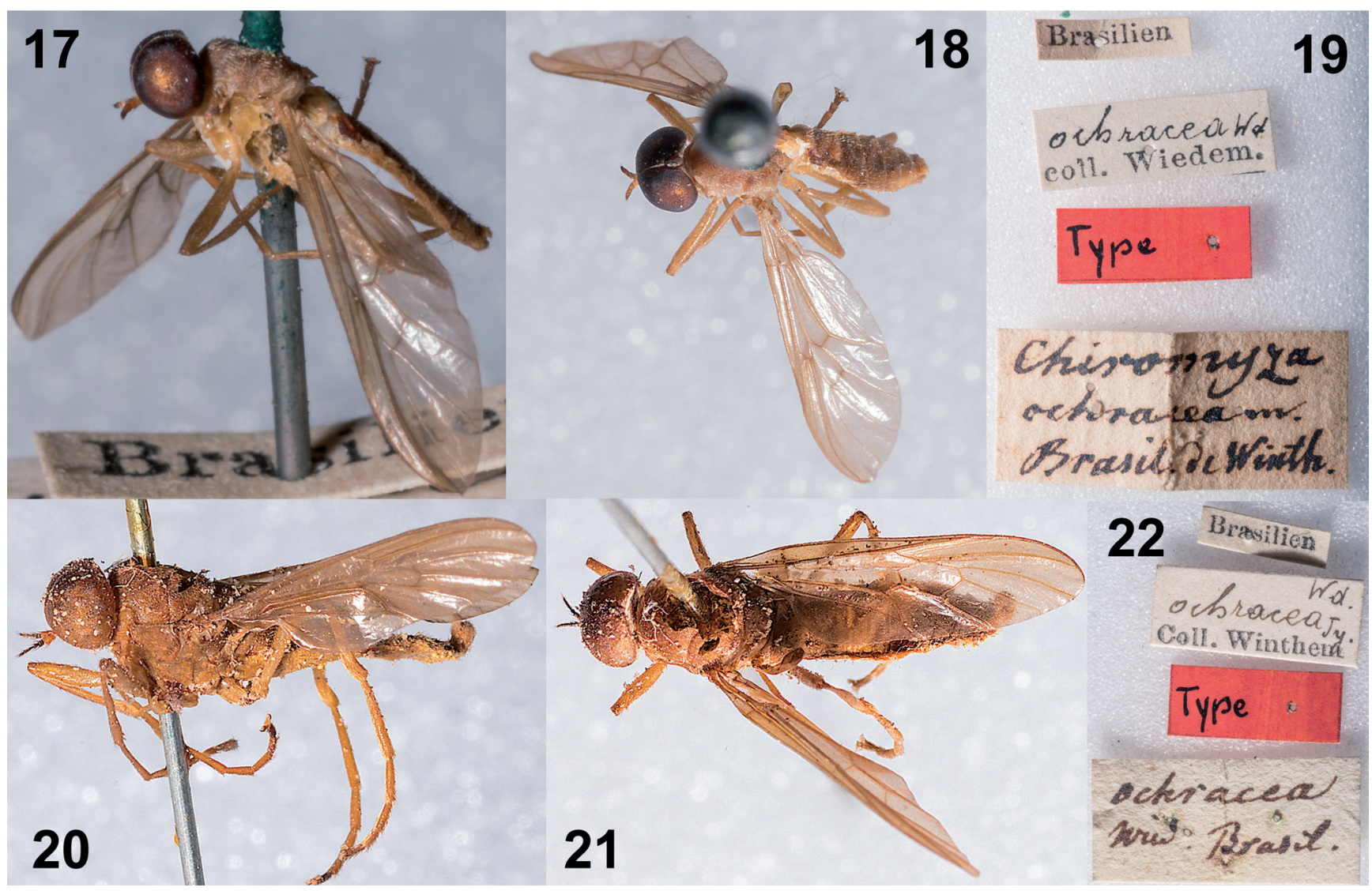

Figures 17-22. Chiromyza ochracea Wiedemann, syntype male (NMW) (17) lateral, (18) dorsal, (19) labels; syntype male (NMW) (20) lateral, (21) dorsal, (22) labels. 
which are housed in Naturhistorisches Museum Wien collection, and were not registred in the Woodley' (2001) World Catalog of the Stratiomyidae. The species of brown soldier flies of the genus Chiromyza are very similar to each other. Despite the accentuated sexual dimorphism, where males are small with holoptic eyes, and females are large ( 2 to 4 times bigger than males) with dichoptic eyes. Furthermore, the Chiromyzinae has been poorly studied in Brazil, which may cause misidentifications even in collections. For this reason, I also searched for specimens of $C$. raccai sp. nov. in other Brazilian collections (DZUB, MNRJ, MZUSP, UFRRJ). Although I didn't find it, I identified some specimens as C. ochracea and C. vittata, as well as other possible new species. Some of the specimens marked as new were lost in the fire at the Museu Nacional (UFRJ) in September 2018.

The three species studied here, Chiromyza raccai sp. nov., C. ochracea, and C. vittata share the pale brown body with few darkened areas. Males of $C$. raccai sp. nov. have four conspicuous thoracic central dark brown stripes (Fig. 2); femurs and tibiae are more strongly clavate (club-like) than in other species (Fig. 1). However, the most notable difference between the three species is in the morphology of the phallus. Chiromyza raccai sp. nov. has the distal region of the phallus rounded with a pair of conspicuous apical setae (Fig. 8), C. ochracea has the distal surface of phallus plan, wide and flat (Fig. 6) and, C. vittata has the distal surface of phallus rounded with outer margin rugose (Fig. 7). On the other hand, the females of C. raccai sp. nov. are much darker than the other species and, they have a conspicuous dark-brown color pattern of thoracic stripes (Fig. 10) and in the dark rings of the femora and tibiae (Fig. 9). The two central thoracic stripes are wider close to the head and tapered towards the scutellum (Fig. 10). The spermathecae are peculiar (Fig. 11), with the genital fork strongly sclerotized, with long and pointed arms (Figs. 12,14). As there was no available identified female material from the other two species, it was not possible to examined and compared the spermathecae morphology with C. ochracea and C. vittata.

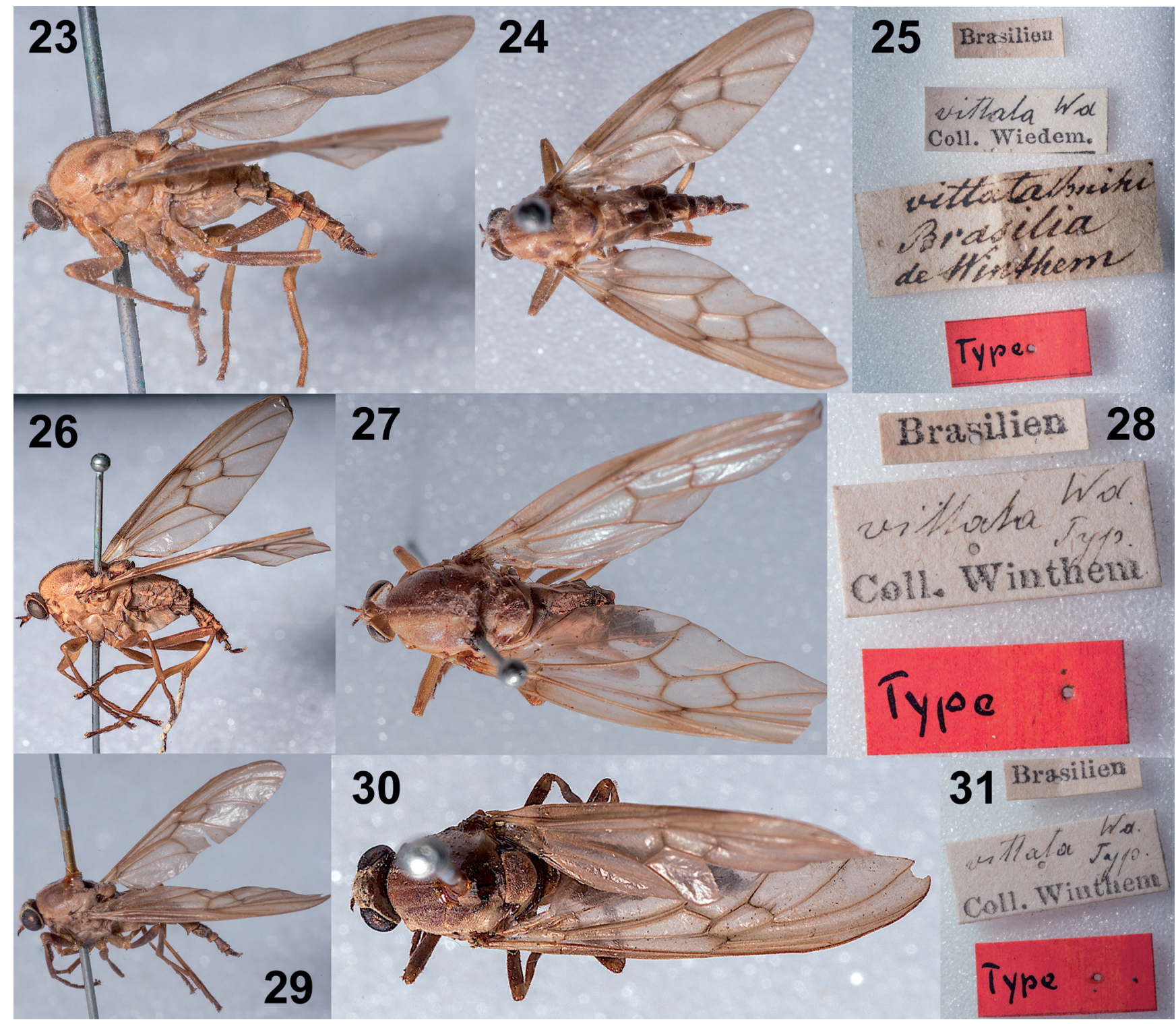

Figures 23-31. Chiromyza vittata Wiedemann, syntype female (NMW) (23) lateral, (24) dorsal, (25) labels; syntype female (NMW) (26) lateral, (27) dorsal, (28) labels; syntype female (NMW) (29) lateral, (30) dorsal, (31) labels. 


\section{ACKNOWLEDGMENTS}

I would like to thank Carlos José Einicker Lamas (MZUSP), Nelson Papavero (MZUSP) and Márcia Souto Couri (MNRJ) and Francisco Racca Filho (UFRRJ), for providing access and loaning of specimens. To Peter Sehnal (NMW, Germany), for imaging type specimens. To Giovanna Souto Morgado (UnB), Alexandre Ariel da Fonseca de Souza (UnB) and André Gardelino Savino (UnB), for assistance with databasing and specimen photography of Diptera collection of DZUB. To Roberto de Xerez (UFRRJ) and Alexandre Ururahy-Rodrigues (UFRRJ), for kindly companionship in the field collection. To Ricardo Bomfim Machado (UNB), for editing the map. To Hélio Ricardo da Silva (UFRRJ), Heloisa Sinatora Miranda (UnB) and João Victor Luz, for reading the manuscript and making helpful comments and suggestions. To Conselho Nacional de Desenvolvimento Científico e Tecnológico, CNPq (Grant 429543/2018-2).

\section{REFERENCES}

Bezzi, M. 1922. On the South American species of the dipterous genus Chiromyza Wied. Annals Entomological Society of America, 15: 117-124.

Cumming, J.M. \& Wood, D.M. 2017. Adult morphology and terminology In: Kirk-Spriggs, A.H. \& Sinclair, B.J. (Eds.). Manual of Afrotropical Diptera. Vol. 1. Introductory chapters and keys to Diptera families. Suricata 4. Pretoria, South African National Biodiversity Institute. p. 89-133.

D’Antônio, A.M. 1991. A descoberta da mosca das raízes. Correio Agrícola, 2: 8-9.
Daniels, G. 2016. A new genus and two new species of soldier fly (Diptera: Stratiomyidae: (hiromyzinae) from Australia, one found infesting sugarcane in central Queensland. Zootaxa, 4092: 572-582.

Hardy, G.H. 1920. A revision of the Chiromyzini (Diptera). Proceedings of the Linnaean Society of New South Wales, 45: 532-542.

Hauser, M.; Woodley, N. \& Fachin, D.A. 2017. Stratiomyidae (soldier flies). In: Kirk-Spriggs, A.H. \& Sinclair, B.J. (Eds.). Manual of Afrotropical Diptera. Vol. 2. Nematocerous Diptera and lower Brachycera. Suricata 5. Pretoria, South African National Biodiversity Institute. p. 919-979.

Lessard, B.D.; Yeates, D.K. \& Woodley, N.E. 2020. Generic revision of the Chiromyzinae soldier flies of Australia (Diptera: Stratiomyidae), including the first record of Boreoides Hardy, 1920, from New Zealand. Austral Entomology, 59(2): 302-322. DOI

Lima, A.F. \& Racca Filho, F. 1996. Manual de pragas e praguicidas, receituário agronômico. Rio de Janeiro, Ed. Universidade Federal Rural do Rio de Janeiro/EDUR. 818p.

Pujol-Luz, J.R. 1999. Notas sobre Chiromyza vittata Wiedemann ou mosca das raízes do café (Diptera, Stratiomyidae, Chiromyzinae). Revista Universidade Rural, Série Ciências da Vida, 21: 161-163.

Pujol-Luz, J.R. \& Oliveira, A.C.D. 1999. Morfologia das espermatecas de Barbiellinia Bezzi e Chiromyza Wiedemann (Diptera, Stratiomyidae). Contribuições Avulsas sobre a História Natural do Brasil (Série Zoologia), 6:1-4.

Pujol-luz, J.R. \& Vieira, F.D. 2000. A larva de Chiromyza vittata Wiedemann (Diptera, Stratiomyidae). Anais da Sociedade Entomológica do Brasil, 29: 49-55.

Wiedemann, C.R.W. 1820. Munus rectoris in Academia Christiano-Albertina iterum aditurus nova dipterorum genera. Offert iconibusque illustrat. Kiliae Holsatorum, C.F. Mohr. viii + 23p., 1 pl.

Woodley, N.E. 2001. A World catalog of the Stratiomyidae (Insecta: Diptera). Myia, 11: 1-475. 